\title{
THE UNFOLDING TENDENCY IN THE FEDERAL RELATIONSHIP TO PRIVATE ACCREDITATION IN HIGHER EDUCATION
}

\author{
MATTHEW W. Finkin*
}

\section{INTRODUCTION}

What follows is a cautionary tale. It is the story of how voluntary associations, that quintessential American phenomenon, were employed to bring some sort of order to higher education-and to keep government at arm's length. It is a story of how government came to rely upon these associations, and of how, over time, that reliance assimilated-or seduced-them into government regulation. It ends, roughly a century after it all began, with these originally autonomous associations becoming extensions of the State.

Nor is that quite all, for the means chosen by Congress to effect that end is freighted with constitutional difficulty. Whereas some of what these associations do is now statutorily subject to administrative oversight and control, in other areas they are left statutorily free. However, as a condition of participation in federally funded programs, institutions of higher education must comply with all accreditation rules whether or not subject to administrative control. This, too, will be explored below.

II

\section{THE ORIGINS AND STRUCTURE OF HIGHER EDUCATION ACCREDITATION}

American higher education took on its modern shape during the waning decades of the 19th and the opening decades of the 20th century, a time of enormous economic, political, and social change to which robust historical characterizations have been applied-the "Progressive Period," the "Age of Reform." The educational leadership of the time scarcely perceived any "system" of higher education at all. In addition to the old colonial colleges, the state institutions for agriculture and the "mechanic arts" spawned by the Morrill Land Grant Act of 1862, and state "normal" schools for teacher training, there appeared a bewildering array of institutions calling themselves "colleges" or

\section{Copyright $(01995$ by Matthew W. Finkin}

* Albert J. Harno Professor of Law, the University of Illinois.

Because the author has served the American Association of University Professors in a variety of capacities, it is important to stress that the views expressed are the author's and not those of the Association. 
"universities," some with modest (or minimal) admissions requirements, some with curricula scarcely qualified to be considered schools of secondary education, and still other graduate institutions founded upon the German model. Contributing to this proliferation was the fact that higher education was seen by a number of religious denominations and a variety of ethnic groups as a means of preserving religious faith or national culture (or both) while educating their youth; by women and blacks as necessary for their separate education, either as an alternative to male- or white-dominated institutions or in response to the fact that a great many of those institutions excluded them; and by local boosters for whom virtually every city or town had to boast a college of its own. Abetting the situation was the fact that the United States lacked a national ministry of education. The conventional wisdom was that education, not being enumerated in the Constitution as a federal concern, was reserved to the states; ${ }^{1}$ and although New York had created a Board of Regents with extraordinary regulatory power over all of education (and many of the professions), in most states there was little or no government oversight.

It was in this environment that a number of voluntary associations were formed: to name the most prominent and enduring, the National Association of State Universities (founded in 1895); the Association of American Universities (founded in 1900); the Association of American Colleges (founded in 1915); and the American Council on Education (founded in 1918). As a student of the phenomenon observed,

degree mills had not been the main cause of worry, but rather inflated claims, difficulty in authenticating valid claims, and uncertainty about standards. Unless moderated, competition for money, students, and prestige threatened to corrupt the academic enterprise. To meet these problems, associationalists believed, the American way of higher education should be nationally systematized-but not by the central government. Embracing the classic liberal conviction that government must be limited, they willingly took on quasi-governmental functions. ${ }^{2}$

The observation was not made of accrediting associations; but it would apply to them with equal force.

Accreditation developed out of two perceived needs: to set some structure for degree-granting institutions as a whole-for example, by establishing a fouryear program of study as the norm for a baccalaureate-and to set substantive standards for education in particular professions. Responsibility for the former was assumed by regional institutional associations. ${ }^{3}$ The oldest, but the last to assume accreditation as an official function, is the New England Association of Colleges and Secondary Schools. It was founded in 1885 by the leaders of several New England preparatory schools to bring some uniformity and

1. On the historical soundness of the conventional wisdom, see GEORGE N. RAINSFORD, CONGRESS AND HIGHER EDUCATION IN THE NINETEENTH CENTURY (1972).

2. HUGH HAWKINS, BANDING TOGETHER: THE RISE OF NATIONAL ASSOCIATIONS IN AMERICAN HigHER EDUCATION, 1887-1950, at 218 (1992).

3. Thumbnail sketches of each of the regional associations are supplied in ACCREDITATION IN Higher EDUCATION 31-73 (Lloyd E. Blauch ed., 1959). 
consistency to the colleges that their graduates would attend. The Middle States Association of Colleges and Secondary Schools was founded in 1889 by several liberal arts colleges in Pennsylvania to deal with the chaos of collegiate admissions practices. (Its concern with college entrance requirements led to the formation of the College Entrance Examination Board.). The North Central Association of Colleges and Secondary Schools was organized in 1895 because the array of secondary schools made it difficult for colleges in the region to assess the qualifications of applicants. But whatever the reasons for their initial founding, the regional associations-of which there are now six ${ }^{4}$-assumed responsibility for accrediting collegiate institutions in each of their respective geographic areas. They are membership organizations of the schools and colleges they accredit; their standards are voted upon by the membership and are applied through commissions they designate. This regional apportionment led, as the associational imperative would suggest, to the formation of a Federation of Regional Accreditation Commissions in Higher Education ("FRACHE") to coordinate and harmonize their operations.

The regionals have had to engage in a delicate balance between the Nation's respect for the principle of institutional autonomy-as well as for the fact of considerable institutional pluralism-and maintaining adherence to externally set standards. Consequently, the struggle over standards has been a consistent theme in the history of institutional accreditation. By the mid-20th century, the regionals had moved away from the more-or-less rigid application of fixed quantitative measures toward acceptance of the idea that an institution should be assessed according to how well it accomplishes the educational mission it has set for itself. But this conception has not wanted for critics; even under this approach, the regionals resisted the idea that they should gauge student achievement or other outcomes as a measure of the extent to which institutions achieve their ends. ${ }^{5}$

Specialized or professional accreditation involves additional complexities. Some professional accrediting is controlled by the organized profession. The real power of these groups lies in securing state laws requiring licensure (often by a state board under the profession's control) as a condition for the performance of professional service, and by requiring graduation from a school or program the profession accredits as a condition of licensure. For some licensed professions, however, the accrediting agency includes the professional schools as an academic counterweight to the skills-oriented norms of practitioners.

4. Southern Association of Colleges and Schools, New England Association of Schools and Colleges, Northwest Association of Schools and Colleges, Western Association of Schools and Colleges, Middle States Association of Colleges and Schools, and North Central Association of Colleges and Schools.

5. Joseph J. Semrow et al., In Search of QualtTy: The Development, Status and FORECAST OF STANDARDS IN POSTSECONDARY ACCREDITATION 134 (1992). 
The variation in the general theme of professional accreditation is usefully illustrated by the case of pharmacy. ${ }^{6}$ Initially, state pharmacy licensing bodies approved schools whose graduates would be permitted to examine for licensure. But the deans of pharmacy schools sought, in the words of one study, "some protection for academic standards against the pressing practicality of licensing boards." "The result was the creation in 1932 of the American Council on Pharmaceutical Education (the "ACPE"), whose governing board consists of three representatives each from the National Association of Boards of Pharmacy, the American Association of Colleges of Pharmacy, and the American Pharmaceutical Association, as well as one appointee of the American Council on Education, an "umbrella" higher education organization that functions significantly in the area of federal relations. A panel of representatives of the "public interest," selected by the ACPE, was later added to advise it on matters of public concern.

Some specialized accreditation is unconnected to any state licensing requirement and is carried out either by member professional schools-for example, by schools of music, journalism, business, or theology-or by the professional or occupational association, as in chemistry and librarianship. The proliferation of specialized accrediting agencies has long been the bane of college and university presidents, as these agencies have attempted to set ever more exacting standards by threatening loss of accreditation, and so lessening institutional prestige. Samuel Capen, who had supported the accreditation movement while an official of the United States Office of Education, complained as Chancellor of the University of Buffalo in a famous 1939 speech:

[R]esponsible administrators of influential institutions in various parts of the country are tired of having the educational and financial policies of their institutions dictated by a horde of irresponsible outsiders, each representing a separate selfish interest.

The issue is plain. Is the American university system to be dominated by competitive blackmail, or is it to be conducted in accordance with the best judgment of the boards and administrative officers charged with this responsibility through charters and through legislative enactments? The American universities gave the standardizing agencies license to live. Whenever the leaders of the universities are ready to unite in the decision that these agencies shall live no longer, they will disappear. I think that day approaches. ${ }^{8}$

It never arrived. ${ }^{9}$

Inasmuch as any group was, and is, at liberty to form an accrediting agency, the question arises as to who accredits the accreditors. That function was taken on in 1949, in keeping with tradition, by a voluntary association, the National

6. See Melvin W. Green, Pharmaceutical Education, in ACCREDITATION IN HIGHER EDUCATION, supra note 3, at 177; see also AMERICAN COUNCIL ON PHARMACEUTICAL EDUCATION, ANNUAL DIRECTORY (1992).

7. Harold Orlans et al., Private accreditation and Public Eligibility 13 (1975).

8. William K. Selden, Accreditation: A Struggle Over Standards in Higher EDUCATION 3 (1960) (quoting speech by Samuel Capen).

9. In 1952, the U.S. Commissioner of Education officially recognized 31 professional accrediting agencies. By 1992, the list had grown to at least 75 . 
Commission on Accrediting (the "NCA"). ${ }^{10}$ It recognized the six regional associations as responsible for accrediting institutions as a whole, and it attempted to limit the growth of specialized accrediting agencies by a policy of limiting the NCA's acceptance to only one agency for any field of study.

In 1975, the NCA and FRACHE merged to form yet another association, the Council on Postsecondary Accreditation ("COPA"), with an expanded constituency that included associations for the accreditation of vocational and proprietary (for-profit) schools. To get a bit ahead of the story, some in higher education quarters argued for the federal government first to rely upon the NCA and later upon COPA to decide which accrediting agencies the government would rely upon. ${ }^{11}$ But that aspiration was never realized. On the contrary, the tensions inherent in COPA's mission, exacerbated by its governance and its expanded constituency proved too great: COPA disbanded abruptly in 1993, leaving the accreditation of accreditation in private disarray ${ }^{12}$ - and in public hands.

\section{III}

\section{THE FEDERAL CONNECTION}

The federal government's relationship to higher educational accreditation has proceeded through three phases. In the first, from 1952 to 1974, the government recognized the determinations of accreditation agencies as adequate indicators of educational quality to qualify the institutions or the students attending them for federal assistance. In the second, from 1974 to 1992, the government continued its reliance, but by administrative action expanded the rules governing its recognition of the agencies, in what one critical study called a period of "quasi-regulation."13 The third began when the Higher Education Amendments of 1992 created a new statutory regime involving far more intense federal scrutiny and accountability.

\section{A. Accreditation as a Facility}

The United States Office of Education was created as a separate department in 1867, but almost immediately became a waif in the federal bureaucracy: from 1869 to 1939, as part of the Department of the Interior, first as the Office of Education, then as the Bureau of Education, then as the Office of Education

10. See generally William K. Selden, The National Commission on Accrediting, in ACCREDITATION IN Higher EDUCATION, supra note 3, at 22.

11. The former proposal is discussed in ORLANS, supra note 7, at 100 . The latter was advanced by the Carnegie Foundation for the Advancement of Teaching in its report. THE CONTROL OF THE CAMPuS 83-84 (1982). The House Subcommittee on Postsecondary Education held hearings on the proposal in 1983. Hearings on Institutional Accreditation, 98th Cong., 1st Sess. (1983).

12. On January 1, 1994, a successor body to COPA, the Commission on Recognition of Postsecondary Accreditation ("CORPA"), was incorporated; but the degree to which it will be able to regulate the world of private accreditation has yet to be determined. CORPA, DIRECTORY: RECOGNIZED ACCREDITING AGENCIES AND SUPPORTERS OF ACCREDITATION 3 (1994).

13. ORLANS, supra note 7 , at 55 . 
again; from 1939 to 1953, as part of the Federal Security Agency; thereafter as part of the Department of Health, Education, and Welfare ("HEW"); and now, as a separate department. ${ }^{14}$ Several Commissioners of Education, and more importantly the chiefs of the division of higher education, enjoyed close, cordial, and supportive relationships with the associational world of higher education. Kendrick Babcock, chief of the division for 1910-1913, later chaired the Association of American Universities committee that issued its own list of accredited institutions in 1913. Samuel Capen, George Zook, and Frederick Kelly all went on to major positions in the associational world. The Commissioner of Education from 1949 to 1953, Earl J. McGrath, had a long and prominent career in university administration. ${ }^{15}$

In 1911, Kendrick Babcock, acting for the Bureau of Education, prepared a classification of American colleges on the basis of the extent to which their graduates were able to complete graduate work without remediation. The impending publication caused a political furor, for it was apparently inconceivable that any institution could be held up by the federal government as anything less than stellar. President Taft ordered publication to be withheld, and President Wilson declined to rescind the order. (Babcock, as noted, later published the list under the imprimatur of the Association of American Universities.) Thereafter, the Bureau of Education ceased any effort to classify or pass judgment upon the quality of collegiate institutions. Instead, it remained content to publish a directory of accredited institutions. To be listed, the institution had to be "accredited or approved by a nationally recognized accrediting agency, a State department of education, a State university, or operating under public control ...."16 Institutions not meeting any of these requirements were listed "if their credits are accepted as if coming from an accredited institution by not fewer than three fully accredited institutions."17 These lists, and the Office of Education itself, were consulted by the Civil Service Commission, the Department of Defense, and other government agencies to determine the bona fides of the educational credentials of applicants for government employment, of chaplains in the military, or for the educational placement of federal personnel.

The Office of Education's statutory power to list "recognized" accrediting agencies was first enacted in the Korean War G.I. Bill in $1952 .{ }^{18}$ The legislative history of that measure has been detailed elsewhere, ${ }^{19}$ suffice it to say here that Congress, concerned that federal monies were being spent for "fly

14. The official history is supplied in R. LYKES, HighER EdUCATION AND THE UNITED STATES OFFICE OF EDUCATION, 1867-1953 (1975).

15. The biographical background is supplied in id. See generally HAWKINS, supra note 2.

16. Jennings B. Sanders, The United States Office of Education and Accrediting, in ACCREDITATION in Higher EDUCATION, supra note 3, at 20.

17. Id.

18. Pub. L. No. 82-550, 66 Stat. 663 (1952).

19. Matthew W. Finkin, Federal Reliance on Voluntary Accreditation: The Power to Recognize as the Power to Regulate, 2 J.L. \& EDUC. 339, 343-48 (1973). 
by night" schools and "blind alley" programs, sought some means of assuring programmatic quality and saw a means toward that end in the established structure of private accreditation. The law authorized state approval agencies to rely upon private accreditation for veterans' educational benefits and directed the Commissioner of Education "to publish a list of nationally recognized accrediting agencies and associations which he determines to be reliable authority as to the quality of training offered by an educational institution ... "20

This approach rested upon three closely related assumptions:

First, the statute assumed that "nationally recognized accrediting agencies" existed and were of sufficient reliability that state government could permissibly piggyback its own approval of courses upon the private agency's decisionmaking processes. Second, reliance upon private determinations of educational quality would obviate the threat of federal control of education. Third, the role of the Commissioner of Education in determining that such nationally recognized agencies were of sufficient reliability would be essentially ministerial. ${ }^{21}$

The third assumption goes to the heart of the recognition-reliance authority: It would be inconsistent with the eschewal of federal control of education to allow the government to control the content of standards for accreditation, to do indirectly what it was directly forbidden to do. ${ }^{22}$

It is well to pause here and inquire preliminarily whether the recognitionreliance structure raised a significant question under the nondelegation doctrine. Since the New Deal era, the thrust of the case law on point has attended to whether Congress has (1) adequately defined the standards its delegate is directed to apply (and whether the delegate has itself adequately channelled its discretion), (2) afforded procedural protections to those adversely affected by the delegate's action, and (3) made judicial review available. It will not do to genuflect before the reality that no federal law has been struck down since that time on nondelegation grounds, for this Act not only presented an almost total lack of any statutory standards to guide the Commissioner (other than the fact of "national recognition" as a "reliable authority"), lacked any requirement for due process for those affected by adverse accreditation decisions, and lacked any provision for judicial review of the delegate's action, but contained the additional factor that the determination of eligibility to participate in a public program was delegated to private groups.

20. Korean War G.I. Bill of 1952, Pub. L. No. 82-550, \& 253, 66 Stat. 663, 675 (1952).

21. Matthew W. Finkin, Reforming the Federal Relationship to Educational Accreditation, 57 N.C. L. REV. 379, 381 (1979).

22. The essentially ministerial character of the Commissioner's role is evidenced in the continuity of its initial criteria for recognition with prior agency practice in its listing for the Educational Directory. See 17 Fed. Reg. 8929 (1952) (error corrected at 17 Fed. Reg. 8994 (1952)). Interestingly, so unremarkable was the statutory authorization that an official history of the Office of Education up to the creation of the Department of HEW in 1953, written in excruciating detail, never mentions it. See LYKES, supra note 14. The law did receive contemporaneous mention in U.S. DEP'T OF HEALTH, EDUCATION, AND WELFARE, 1953 ANNUAL REPORT 188 (1954), but only briefly and in conjunction with mention of staff service in a seminar held by the American Association of Dental Examiners. 
That special feature-of the nondelegation of public power to private parties-has had a checkered career before the United States Supreme Court; ${ }^{23}$ but it is accurate to say, as James O. Freedman has, that there is a genuine concern of whether "private persons, even though they have been selected by Congress, can be relied upon to exercise the sovereign power of the nation with a disinterestedness sufficient to assure that the interests of all of those subject to regulation will receive fair consideration . . ."24 The courts, he notes, "commonly have sustained delegations to private parties in the form of statutes that attach public consequences to decisions that the delegate has made or would be making in any event for purposes quite independent of giving content to the legislation." ${ }^{25}$ He takes as illustrative of such a permissible delegation the regulation of drugs defined by statute as those listed in the United States Pharmacopoeia, a publication of the Pharmaceutical Manufacturers Association.

[T] he private party's decision to include or exclude a particular drug is invariably made according to pre-existing professional standards in order to serve a particular professional need, rather than as a response to the legislation that gives such decisions a coincidental public effect. Delegations of this kind carry considerable assurance that the private party's action will be guided not by self-interest but rather by extrinsic standards, usually formulated and endorsed by a professional community, designed to serve a larger social interest. ${ }^{26}$

Such uses abound: from statutory commands to workers' compensation boards to rely upon the American Medical Association's Guides to the Evaluation of Permanent Impairment, ${ }^{27}$ to the public mandate, often merely by reference, of privately promulgated product standards. ${ }^{28}$ In point of fact, a

23. See generally George W. Liebmann, Delegation to Private Parties in American Constitutional Law, 50 IND. L.J. 650 (1975) (thoroughly reviewing the law and literature). More recently, the Court found no due process infirmity in a Texas law requiring that four of the six members of the regulatory Texas Optometry Board be members of the Texas Optometric Association, noting the broad discretion accorded the states to engage in "economic" regulation. Friedman v. Rogers, 440 U.S. 1, 18 n.19 (1979). But it did hold infirm, on First Amendment grounds, a Massachusetts statute that granted churches a veto power over the issuance of liquor licenses. Larkin v. Grendel's Den, Inc., 459 U.S. 116 (1982). The Court noted that it was not called upon in the case to decide "whether, or upon what condition, such [licensing] power may ever be delegated to nongovernmental entities ...." Id. at 122 (emphasis added). Contrary to the Supreme Court's altogether brief dismissal of the due process challenge to the membership requirement for the Texas Optometry Board, the designation of private professional organizations as nominators for state regulatory agency membership has continued to vex the state courts. See Rogers v. Medical Ass'n of Ga., 259 S.E.2d 85 (Ga. 1979); United Chiropractors of Wash., Inc. v. State, 578 P.2d 38 (Wash. 1978). Contra Kentucky Ass'n of Realtors v. Musselman, 817 S.W.2d 213 (Ky. 1991).

24. James O. Freedman, Delegation of Power and Institutional Competence, 43 U. CHI. L. REV. 307, 332-33 (1976). As will appear presently, the question presented here is not of federal constitutional limits upon what the states may choose to do in the area of "economic regulation"-an area in which the Court has given the states the widest latitude-but of the limit upon Congress to delegate to private parties power to act in an area of special concern to the First Amendment.

25. Id. at 333.

26. Id.

27. This reliance has been criticized in Ellen S. Pryor, Flawed Promises: A Critical Evaluation of the American Medical Association's "Guides to the Evaluation of Permanent Impairment," 103 HARV. L. REV. 964 (1990).

28. See generally Robert W. Hamilton, The Role of Nongovernmental Standards in the Development of Mandatory Federal Standards Affecting Safety or Health, 56 TEX. L. REV. 1329 (1978). 
number of federal statutes relied upon the fact of educational "accreditation" without further provision for, or reference to, any authority by the relevant government agency to grant "recognition" to such agencies, let alone authority to regulate them in any way.9

It is not at all clear that the recognition-reliance system worked a "delegation" even in the sense of these instances of public reliance on private standards. The provision could be looked at, in essence, as requiring that an institution be of good reputation in the academic community. Toward that end, the Act could have required the Commissioner of Education to conduct a poll of the institutions it listed in the Education Directory for a showing of each institution's general acceptance. Such a requirement would not "delegate" any public power-and may better explain a line of decisions of the Supreme Court sustaining the requirement of a vote of private parties as a condition of public action. $^{30}$ From this perspective, reliance upon accreditation would be viewed as an efficient surrogate for such a poll.

Alternatively, were the situation taken to be one where government, rather than set its own qualitative standards, delegates that task to private entities, the conditions Freedman outlines ${ }^{31}$ (and which justify reliance in these other cases) would have been met: The accrediting agencies would not be acting in response to the legislation nor at the behest of the legislature. They would continue to go on as they had before, which standard-setting and standard-applying could then be relied upon by government agencies as a facility.

As the federal government came directly to aid higher education and to assist students to secure advanced education, through the National Defense Education Act (the "NDEA") of $1958,{ }^{32}$ the Higher Education Facilities Act of $1963,{ }^{33}$ the Health Professions Educational Assistance Act of the same year, ${ }^{34}$ the Nurse Training Act of $1964,{ }^{35}$ and, most important, the Higher Education Act of $1965,{ }^{36}$ the recognition-reliance structure was retained and refined. Provision was made for "developing" institutions, those that were not

29. Some of these are listed in Finkin, supra note 21, at 393 n.56.

30. See, e.g., Currin v. Wallace, 306 U.S. 1 (1939). The Tobacco Inspection Act authorized the Secretary of Agriculture to designate markets where tobacco could be sold, and so subject to federal inspection and grading, upon vote of two-thirds of the growers. The provision was attacked on delegation grounds by tobacco warehousemen and auctioneers. The Court rejected the challenge:

Congress has merely placed a restriction upon its own regulation by withholding its operation as to a given market "unless two-thirds of the growers voting favor it." Similar conditions are frequently found in police regulations. This is not a case where a group of producers may make the law and force it upon a minority.... Here it is Congress that exercises its legislative authority in making the regulation and in prescribing the conditions of its application. The required favorable vote upon the referendum is one of these conditions.

Id. at 15-16 (citations omitted). For a more recent application of this approach, see Kentucky Div., Horsemen's Benevolent \& Protective Ass'n v. Turfway Park Racing Ass'n, 20 F.2d 1406 (6th Cir. 1994).

31. See Freedman, supra note 24.

32. Pub. L. No. $85-864,72$ Stat. 1580 (1958).

33. Pub. L. No. 88-204, 77 Stat. 363 (1963).

34. Pub. L. No. 88-129, 77 Stat. 164 (1963).

35. Pub. L. No. 88-581, 78 Stat. 908 (1964).

36. Pub. L. No. 89-329, 79 Stat. 1219 (1965). 
accredited but for which there was reasonable assurance that they would become accredited. Statutory provision was also made for an unaccredited institution to be included if its academic credits "are accepted, on transfer, by not less than three" accredited institutions. ${ }^{37}$ This provision, the "three letter" rule, was included at the insistence of orthodox Jewish and Greek schools and "serious" colleges which remained unaccredited due to weak finances, ${ }^{38}$ but the "three letter" rule had been established as policy for listing in the Office of Education's higher education directory prior to the 1952 Act. In sum, the essentials of the 1952 reliance structure, and the legislative assumption upon which it rested, continued unchanged.

\section{B. Slouching Toward Regulation}

The Higher Education Act of 1965 and subsequent legislation, especially the National Vocational Student Loan Insurance Act of the same year ${ }^{39}$ and the Higher Education Act of $1972,{ }^{40}$ increased the federal dollars flowing for student assistance and, more important to the issue here, expanded the nature of the education for which those students could secure support. These acts created a new world of federally supported "postsecondary" education. ${ }^{41}$ As a leading study points out, a major problem with this broadened inclusiveness was that the antecedent quality control system, reliance on private accreditation, hinged upon a concept of institutional eligibility that derived from the stable world of traditional public and nonprofit degree-granting institutions. ${ }^{42}$ The concept was inapplicable to the world of vocational education, in which the key concern is the individual course of instruction-in fingerprinting, clothes pressing, beauty culture, barbering, modeling, Swedish massage, dog grooming, floristry, belly dancing, or baby care. These courses are offered not only in stable, publicly operated community colleges or vocational/technical schools, but also in the unstable world of anywhere from 7,000 to 30,000 proprietary schools

37. Id. § 461,79 Stat. at 1268.

38. ORLANS, supra note 7, at 41 . The Department of Education later adopted and secured judicial approval of its interpretation of the "three letter" rule, requiring that three accredited institutions actually had credited such transfer students, and rejecting a reading that would have rendered the unaccredited institution eligible if it could show that three such institutions would accept the nonaccredited institution's credits on transfer. Beth Rochel Seminary v. Bennett, 825 F.2d 478 (D.C. Cir. 1987).

39. Pub. L. No. 89-287, 79 Stat. 1037 (1965).

40. Pub. L. No. $92-318, \S 101(\mathrm{~b}), 86$ Stat. 236 (1972).

41. ORLANS, supra note 7 , at 159-60:

"Postsecondary" education is an eminently democratic concept that seeks to equate, for purposes of public policy, planning, and student aid, the education of physicians and nurses aides, of physicists and plumbers, of Ivy League freshmen and 17-year-old high school dropouts who return to school to learn a trade. "Eleven hundred community colleges have more clout than forty-five members of the AAU" (The Association of American Universities), remarked one OE [Office of Education] official in a 1972 interview. "For years it has been national policy to help a student to study Greek, but not to learn a trade," said another OE official. "Postsecondary" education seeks to correct that and to hold out the prospect of continuing education of any and every kind at any and every adult age.

42. Id. 
(no one seems to know quite how many) that might close, reopen, change hands, or alter their courses on a moment's notice. ${ }^{43}$ Nevertheless, for whatever reason-effective lobbying by the trade associations of proprietary schools, ${ }^{44}$ the implications and costs of federal institutional inspection, the weaknesses of the states as regulators, or the reluctance of the Office of Education to acknowledge the lack of fit-the recognition-reliance system was retained in this setting.

In 1968, the Commissioner of Education began to expand the role of his office vis-à-vis the "recognition" of accrediting agencies. The Office created an Accreditation and Institutional Eligibility Staff (the "AIES") and an Accreditation and Institutional Eligibility Advisory Committee to review all policies, develop criteria for recognition of accrediting agencies, recommend the actual designation of agencies for recognition, and maintain general oversight. Initially there was close cooperation between the two government groups and the accreditation community: The first director of the AIES, John Proffitt, had been assistant director of the NCA; the Advisory Committee was chaired by Frank Dickey, NCA director, and included Norman Burns, staff director of FRACHE and of the Commission on Higher Education of the North Central Association.

In 1969, the Office of Education issued its first revision of recognition criteria since 1952 . These criteria closely tracked the practice established by the regionals and the $\mathrm{NCA}$, in the latter case by incorporating for the first time the NCA's restriction limiting recognition to one agency for each geographical area and for any defined field or specialization in order to dampen the longcondemned proliferation of accrediting agencies. Thereafter, the relationship between the Office of Education and the accrediting community cooled. Dickey's and Burns's terms expired, and the AIES began to take a more aggressive view of its role. The tocsin was sounded in a 1970 address by John Proffitt in a meeting sponsored by the Office of Education and the NCA:

[A]ccrediting bodies are performing an increasingly important societal role-a role in service to the broader society rather than one solely in service of the narrower educational community. And if the Federal Government is going to be justified in

43. Id. at 48. Congress later enacted limits on institutional eligibility geared to the student default rate on federally insured loans. The default rates for loan repayment in 1990 threatened the eligibility of 55 public and nonprofit institutions, mainly community colleges and vocational centers, but also threatened were more than 850 proprietary trade schools. Jim Zook, 900 Institutions Could Be Dropped from Student-Aid Programs for High Loan-Default Rates; 55 Are Non-Profit Colleges, CHRON. HIGHER EDUC., Sept. 1, 1993, at A30. The annual rate of loan default from 1988 to 1991 for all eligible schools was $17.5 \%$, which statistic included a default rate of $35.9 \%$ for proprietary schools alone. Id. at A31. The termination of eligibility pegged to student default rates has been sustained. Pro Schools, Inc. v. Riley, 824 F. Supp. 1314 (E.D. Wis. 1993).

44. The effectiveness of lobbying efforts by these groups cannot be scouted. Congress did enact a provision requiring proprietary schools to receive at least $15 \%$ of their income from sources other than federal student aid programs, which provision was to take effect on July 1,1994 . But after heavy lobbying by trade schools and their associations, the House voted to delay enforcement of the rule for one year. Jim Zook, Trade Schools Increased Gifts as House Debated Aid Measure, CHRON. OF HigHER EDUC., Sept. 14, 1994, at A54. 
continuing strong reliance upon private accreditation, the accrediting associations will need to more explicitly recognize their obligation to protect the public interest. ${ }^{45}$

In 1974, the Commissioner published new criteria for the recognition of accrediting agencies. These new criteria attempted to make the accrediting agencies recognize their obligation better to protect the public interest by requiring that each agency show among other things that (1) it is "responsive to the public interest" in that it includes "representatives of the public in its policy and decisionmaking bodies, or in an advisory or consultative capacity," (2) it has "demonstrated capability and willingness to foster ethical practices among the institutions or programs it accredits, including equitable tuition refunds and nondiscriminatory practices in admissions and employment," and (3) it "encourages experimental and innovative programs." 46 The leading study of the recognition-reliance system at the time was highly critical of all these requirements. ${ }^{47}$ The extensive criticism under each head need not be rehearsed. The single example of the requirement of "public" representation should suffice.

On one level, the requirement raises both theoretical and practical problems of just who represents "the public":

To whom is the "public" member responsible? If we cannot define the public and it plays no part in appointing him, he has no way of reporting to or consulting with it. If he is appointed by the accrediting agency and yet is responsible to an unidentified public, he can be responsible only to his idea of the public, which is to say, to his own educational and political conscience. That makes him irresponsible from the standpoint of his fellow accreditors, who must account for their actions to members of their association. ... In short, he cannot be what is purported: a representative of, or spokesman for, the "public." 48

The point is brought home in a current controversy in pharmacy education. Upon the initiative of American Association of Colleges of Pharmacy, the American Council on Pharmaceutical Education has moved toward replacing its accreditation of the baccalaureate of pharmacy, a program that ordinarily requires at least five years to complete, with the doctorate of pharmacy, a program that requires at least six years to complete, as the only first professional degree it will approve. The move is premised in part upon an effort to change the very nature of the practice of pharmacy, to one more fully in

45. John Proffitt, Address at the Meeting Sponsored by the U.S. Office of Educ. and the Nat'1 Comm. on Accrediting (Nov. 6, 1970), quoted in Finkin, supra note 19, at 371.

46. Criteria for Recognition of National Accrediting Bodies and State Agencies, 39 Fed Reg. 30,041, 30,043 (1974).

47. "How, it asked, is the National Association of Schools of Music and the Accrediting Association of Bible Colleges to introduce innovation into Mozart and the Ten Commandments?" ORLANS, supra note 7 , at 75 .

48. Id. at 98. One commentator applauded the requirement of "public representatives" as helping to "ensure the autonomy" of accrediting agencies and as inserting "into the process persons representative of broader interests." William A. Kaplin, Accrediting Agencies' Legal Responsibilities: In Pursuit of the Public Interest, 12 J.L. \& EDUC. 87, 112 (1983). The author makes no reference to the above, contradicting that conclusion. 
partnership with physicians and other health care professionals. ${ }^{49}$ It has been strongly criticized by the National Association of Chain Drug Stores (the "NACDS"), whose members employ more than 65,000 of 173,000 practicing pharmacists, on the ground that the anticipated model of pharmacy practice is unrealistic, improbable, and, in any event, unnecessary for the kind of skills its members expect pharmacists to need. ${ }^{50}$. The drug store association has argued that the change will drive up the costs of pharmacy education and, it might be added, will also tend to drive wages up to the extent the requirement of an additional year's study will reduce the supply of those with the requisite advanced education.

The ACPE has an advisory committee, appointed by it, of three members of "the public," as federal rules require. But how is the "public interest" best served in this matter? Is it better for society to have all future pharmacists capable of performing in a more sophisticated practice environment? At what additional cost? Even if that level of sophistication actually turns out not to be needed for the practice of pharmacy in some or even many settings? Is the added cost to pharmacy students, to the institutions devoted to training them (and at the expense of other programs to which those funds might be devoted), or to the consumers of pharmacy services worth the benefit? How are three "public members" appointed by the ACPE and accountable only to themselves to answer these questions?

Apart from these theoretical and practical questions, some of the 1974 criteria-"public" membership is a good example-raised a significant legal issue for they were inconsistent with the fundamental premises of the recognition-reliance facility:

\footnotetext{
Whereas these modifications are premised upon a concern that private accrediting agencies become more attuned to the "public interest, as opposed to parochial . . . interest," and that the Commissioner's criteria serve as a stimulus for progressive and responsible change, the statutes that authorize the publication of a list of accrediting agencies are premised upon the assumption, akin to the Invisible Hand, that when accrediting agencies act in their own narrow parochial interests, their determinations are sufficiently reliable for the government to accept; thus, nothing in the statutory authority for the Commissioner's list would appear to authorize him to require that otherwise reliable agencies alter their policies to achieve what the Commissioner deems to be progressive social policy. ${ }^{51}$
}

At this point, the accrediting community would have been on solid legal ground to have rejected some of the new criteria as beyond the government's power to list "nationally recognized" accrediting agencies. But they had become too deeply enmeshed with the Office of Education: The Office needed them in order to carry out its institutional approval authority, and they needed the

49. See generally American Ass'N OF COlleges of PhaRmacy, SPECial RePORT OF the COMMission to IMPLEMENT Change in PhaRmaceUtical EduCation (Nov. 1991).

50. NACDS Response to Federal Register Notice Regarding the American Council on Pharmaceutical Education (ACPE) May, 1991 Interim Report to the U.S. Department of Education (on file with author).

51. Finkin, supra note 21 , at $390-91$. 
Office for official recognition-for the prestige and power that that recognition accorded. ${ }^{52}$ They complained, ${ }^{53}$ but they complied.

In 1988, the Secretary adopted another revision of the criteria for recognition and listing. Gone was the requirement of encouraging innovation. Gone also was the requirement that institutions police nondiscrimination in admissions and employment. These were omitted as not having "a direct impact upon the ability of accrediting agencies to be reliable authorities as to educational quality." 54 The question of discrimination, the Secretary opined, was adequately covered in federal civil rights laws. ${ }^{55}$

The new criteria also abandoned the 1969 policy restricting listing to a single agency. This policy had been criticized as irrelevant to the Secretary's function, and as antithetical to consumer interests and to institutional pluralism. ${ }^{56}$ The critics assumed that the prestige of adhering to the ostensibly more rigorous standards of one of several available agencies would act as a counterweight to any general movement toward the lowest common accreditor.

These modifications brought the Secretary back into closer conformity with the statutory assumptions of the recognition-reliance system. But the fig leaf requirement of public membership, omitted in the proposed rule, was retained at the request of commentators. ${ }^{57}$ And in the most objected-to provision, the criteria placed greater emphasis than before upon the accrediting agency's assessment of student achievement as a measure of the institution's or program's success, an issue, it was noted earlier, that had long vexed the accrediting agencies but which, the Secretary opined, "reinforced a current trend" in accreditation. ${ }^{58}$ Whether or not that was an accurate assessment, accreditors had been warned a year earlier that governmental establishment of the criteria

52. ORLANS, supra note 7 , at 102.

53. In 1974, Frank Dickey, Executive Director of the National Commission on Accrediting, testified before the Senate:

[A]ccrediting organizations have been enticed to become reluctant extensions of the U.S.

Office of Education in order that the accredited schools, programs, and colleges might share in the largesse writ large. Many now would like to break off the relationship, and some have indicated they intend to do so, in order to return to the prerogative which historically and professionally has belonged to them-that of promoting and insuring quality programs of education. All are capable of doing just that and are perfectly willing to abide the scrutiny of the federal benefactor in so doing. They are not willing much longer to abide the prod which inevitably has followed the scrutiny.

Hearings before the Subcomm. on Education of the Senate Comm. on Labor and Public Welfare, 93d Cong., 2d Sess. 237 (1974).

54. Secretary's Procedures and Criteria for Recognition of Accrediting Agencies, 53 Fed. Reg. $25,088,25,095$ (1988) [hereinafter Secretary's 1988 Criteria].

55. Id. at 25,096 .

56. Finkin, supra note 21 , at 394 (reviewing the criticism). In consequence, when the National Association of Chain Drug Stores protested to the Department of Education about the ACPE's proposed restriction of its accreditation to the doctor of pharmacy as a first professional degree, the Department pointed out that institutions in disagreement with the change were free "to establish an alternative accrediting agency with standards more in line with their needs," though any such agency would have to persuade state licensing authorities of the validity of its standards.

57. Secretary's 1988 Criteria, supra note 54, at 25,095-96.

58. Id. at 25,090 . 
that accrediting agencies would have to apply would convert them from "quasipublic" agencies into "quasi-governmental" ones. ${ }^{59}$ Despite the warning, the agencies complied. ${ }^{60}$

At this point, the scope of the Secretary's power was brought into the public forum as a result of action taken by the Commission on Higher Education of the Middle States Association. ${ }^{61}$ The Middle States standards required the institution to "have a governing board which includes a diverse membership broadly representative of the public interest and reflecting the student constituency." They also included other "diversity" criteria in admissions, faculty, and curricula, set out below. ${ }^{62}$

On March 7, 1990, after discussion going back several years, Middle States issued an order to the Westminster Theology Seminary to "show cause" why its accreditation should not be removed for its failure to include women on its governing board. Westminster explained that its constitution required that the board be composed of elders in the sponsoring denomination, that church doctrine forbade the ordination of women, and that acceding to the Middle States position would accordingly infringe upon its religious autonomy. Nevertheless, Middle States persisted in its view.

At about the same time, Middle States informed the Baruch College of the City University of New York that it had deferred action on Baruch's reaccreditation pending further discussion based upon its inspection team's concerns for

59. SEMROW ET AL., supra note 5, at 134.

60. As one study explains,

the concern about governmental influence reached new heights when Secretary of Education William Bennett promoted assessment and outcomes criteria in new rules for the government recognition of accrediting agencies. Thurston Manning, who succeeded Millard as COPA director, questioned anew the role of the federal government, and charged that the federal government was going beyond its role to influence the choice of accrediting criteria. In 1987, during the discussions of the new legislation, the federal government's new regulations set outcome measures as one of the criteria for recognition. The [North Central Association's] Commission revised its materials to reflect the government's requirements.

Id. (references omitted).

61. A fuller account is supplied in Jeffrey C. Martin, Recent Developments Concerning Accrediting Agencies in Postsecondary Education, 57 LAW \& CONTEMP. PrOBS. 121 (Autumn 1994).

62. U.S. Dep't of Educ., Staff Report to the National Advisory Committee for the Meeting (Nov. 21-22, 1991) (on file with author). The relevant standards provided, inter alia:

Admissions. "An important index of an institution's caliber is its admissions policy as evidenced in requirements, standards, and procedures, and in the efforts it makes to achieve diversity in the student population." "Programs and curricula need to be sufficiently diversified to provide educational opportunities commensurate with the obligations inherent in a responsible admissions policy."

Faculty. "The selection of the faculty must avoid parochialism and excessive inbreeding. Steps must also be taken to achieve appropriate diversity of race, ethnicity, gender, and age in faculty ranks." "Educational institutions should contain within their environment the essence of the qualities they endeavor to impart, including justice, respect for diversity and human dignity, and equity."

Program and Curricula. "Where possible a global perspective should be introduced to emphasize the cultural diversity and interrelatedness of the contemporary world."

The following account and references are taken from the U.S. Dep't of Educ., supra, at 3-4. 
the "paucity of minority representation" on the faculty and in the administration. The report of a follow-up visit criticized Baruch for not making "a serious effort to recruit and retain African-American and Latino faculty members beyond competing ineffectively for the very top scholars who inevitably gravitate to institutions with greater resources and prestige." The team concluded that "Baruch College ha[d] emphasized traditional academic values without exhibiting equal concern for the values of social justice and equity critical to serving working people in a multicultural urban environment."

In light of these two cases, the Secretary deferred action on Middle States's petition for renewal of its listing by the federal government, in consequence of which a subcommittee of the House Committee on Government Operations held hearings to call the Secretary to account. To the subcommittee chairman, the Secretary's action signalled a retreat from the defense of civil rights and was contrary to the statutory prohibition of federal control of accreditation standards. ${ }^{63}$ To the Secretary, Middle States's action placed in question its own reliability and was ultra vires. ${ }^{64}$ A few months later, Middle States modified its rules to provide that each institution is free to define for itself the "nature and scope of diversity to be applied, consistent with its own missions, sponsorship, beliefs, and legal requirements." ${ }^{65}$ It also provided that its "equity

63. Hearings before the Human Resources and Intergovernmental Relations Subcomm. of the Comm. on Government Operations, 100th Cong. 1st Sess. 1-2 (1991) (remarks of Mr. Weiss).

64. Secretary Alexander testified:

I came into the Capitol Building this morning through a screening device by a policeman. I assume Congress wants to keep people out with guns or ensure only people who were safe came into the Capitol, and made an arrangement with a private security company or some security company or its own employees to keep people out who weren't safe.

I suppose it would be possible for some security guard to also come in to you, $\mathrm{Mr}$. Chairman, and say:

Well, I have done my job very well. In addition to that, I have also made sure that half of the people who are spectators at the hearing today are women, and every other person is either an Asian American or a person of African American heritage. I am also not letting anymore Methodists in until we get more Baptists in, and I told some of the Presbyterians to change their religious belief.

I think what you might say to the guard was:

Those are all very important issues, but we didn't hire you, or make an arrangement with you, to make decisions about the number of men and women in the Gallery or the religious beliefs of the people coming through the screening procedure.

We didn't ask you to decide what the composition racially, or by ethnic origin, ought to be of our staffs or of the people who are spectators in the Gallery.

Those are very important issues, but those are issues for other people to decide. We have a Constitution.

Congress has passed some laws. We have some Federal agencies with those decisions, and we don't need a person that we hired to be in charge of security to be making those decisions for us, or for the other agencies.

Id. at 14-15.

65. U.S. Dep't of Educ., Supplemental Staff Report to the National Advisory Committee 1 (Jan. 6,1992 ) (on file with author). 
and diversity" principles were not to be mandatory conditions of accreditation. On that basis, Middle States's recognition was continued.

C. The 1992 Act

It was in this environment that Congress fashioned the Higher Education Amendments of $1992,{ }^{66}$ a major overhaul of a statutory structure that, on the issue of accreditation policies, had remained essentially unchanged since the Higher Education Act of 1965 and its antecedents. The 1992 Act addressed the problems of fraud and abuse by breathing new life into the role of state oversight. The Act provided for state "postsecondary review entities" to contract with the Department of Education and defined the scope of their review to include program completion rates, student withdrawal and placement rates, advertising, and the appropriateness of the clock hours required for course or program completion. ${ }^{67}$ The Act made institutional eligibility to participate in student loan programs subject to termination upon state determination of institutional noncompliance with the review standards set. ${ }^{68}$ But there was a major difference between the House and the Senate on continuation of the requirement for accreditation.

The House bill would have severed the connection for student loan purposes; the Senate retained the requirement, and the Conference acceded to the Senate's position. ${ }^{69}$ The result was an elaborate scheme of federal requirements and controls. Essential elements of this scheme include the separation of the accrediting agency "both financially and administratively" from any related trade association or membership organization (subject to a waiver for grandfathered associations), which provision is expanded upon. The requirement of public membership on the agency's governing board is codified. ${ }^{70}$ Aspects of the agencies' operating procedures are specified, including the observance of due process in evaluation and withdrawal of accreditation; and submission of disputes over denial or termination of accreditation to "initial arbitration" is required after which jurisdiction is expressly given to federal district courts. ${ }^{71}$

Most important, accrediting agencies must meet standards to be set by the Secretary, via a negotiated rulemaking, which require measures of student achievement to be employed. In addition, the standards require the accrediting

66. Pub. L. No. 102-325, 106 Stat. 448 (codified as amended in scatterd sections of 11, 20, 25, and 42 U.S.C.).

67. Id. at $639-41$ (codified at 20 U.S.C. $\$ 1099 \mathrm{a}-3$ ).

68. The far more exacting requirement of state scrutiny is beyond the scope of this discussion. It suffices to say that the full implications of that scrutiny, especially on first amendment grounds, remain to be developed. Thus far, New York's separate rules for proprietary institutions have withstood facial challenge. New York State Ass'n of Career Sch. v. State Educ. Dept., 823 F. Supp. 1096 (S.D.N.Y. 1993). 40.

69. The political background of the 1992 amendments is discussed in Martin, supra note 61, at 139-

70. 20 U.S.C. $\$ 1099 \mathrm{~b}(\mathrm{~b})(2)$ (Supp..IV 1992).

71. Id. $\S \S 1099 \mathrm{~b}(\mathrm{c}),(\mathrm{e}),(\mathrm{f})$. 
agency to assess the institution under eleven other heads-including faculty, curricula, admissions practices, completion rates, default rates in student loan programs, and facilities. ${ }^{72}$ The Act permits the Secretary to limit or terminate approval of an accrediting agency if, after notice and a hearing, the Secretary determines that the agency has "failed to apply effectively" the standards or procedures set out in the Act. The Secretary has further authority to evaluate comprehensively the performance of agencies seeking recognition apart from an agency's application of the statutory standards in any individual case. ${ }^{73}$

Three other aspects of the Act bear mention. First, the Act assumes that more than one accreditation agency may serve the same institution or program, thus codifying the 1988 policy of potential multi-agency recognition, by requiring an institution that changes its accrediting agency to demonstrate "reasonable cause" for doing so. ${ }^{74}$ Where the institution "as an institution"-so to distinguish specialized accreditation from institutional accreditation-maintains accreditation by more than one agency, it too must demonstrate "reasonable cause" for that action. In other words, the Act tacitly accepts the idea of competition among accrediting bodies, but seeks administratively to limit an institution's freedom to shop for the lowest common accreditor. ${ }^{75}$

Second, the Secretary's authority is cabined: He or she may not establish standards "not required" by the Act. ${ }^{76}$ Concomitantly, accrediting agencies are statutorily free of any constraint in adopting "additional standards not provided for" in the Act. ${ }^{77}$

Finally, the Act denies participation in any of the enumerated federal programs to any unaccredited institution or program, including one whose accreditation has been terminated or voluntarily withdrawn. ${ }^{78} \mathrm{~A}$ separate but related amendment struck the "three letter" alternative, ${ }^{79}$ thereby reinforcing the requirement of accreditation. However, provision is made for the Secretary to continue an institution's eligibility for a period of time to allow it to secure alternative accreditation if (1) it is an institution with a religious mission or affiliation, (2) its accredition has been terminated or withdrawn, even voluntarily, for a reason related to its religious mission or affiliation, and (3) that reason is not "related to" the accreditation standards provided for in the Act. ${ }^{80}$ According to the Conference Report, this provision was fashioned in conference

72. Id. § $1099 \mathrm{~b}(\mathrm{a})(5)$.

73. Id. $\$ \$ 1099 \mathrm{~b}(1) \&(\mathrm{n})$.

74. Id. \& $1099 \mathrm{~b}(\mathrm{i})$.

75. The role of competition among accrediting agencies in the context of the 1992 amendments is discussed more fully in Martin, supra note 61, at 133-36.

76. 20 U.S.C. $\$ 1099 \mathrm{~b}(\mathrm{~g})$ (Supp. IV 1992).

77. $I d$.

78. $1 d . \& 1099 \mathrm{~b}(\mathrm{j})$.

79. See supra notes $37-38$ and accompanying text.

80. 20 U.S.C. \& $1099 b(\mathbf{k})$. 
to provide for the Secretary to extend the eligibility of an institution whose accreditation was revoked because of a religious mission or for a reason unrelated to the accreditation standards established in this Act in order for the institution to become accredited by another accrediting body. ${ }^{81}$

But the emphasized disjunctive did not appear in the text of the bill as reported; it read in the conjunctive, thereby attending only to the situation of a religiously affiliated institution. ${ }^{82}$

The distinction between the scope of approval and matters insulated from government review, coupled with the distinction between religiously and nonreligiously based institutional disagreements over standards unrelated to the Act's requirements, is freighted with questions of considerable magnitude. These issues are best explored by revisiting the "diversity" controversy.

\section{IV}

\section{DELEGATION AND "DIVERSITY"}

For the sake of analysis, assume that the Middle States Association were to reinstitute the diversity rules that got it into so much difficulty with the Secretary of Education under prior law. Should Middle States proffer these standards as "related to" the agency's assessment of the institution's faculty, student admissions, and curriculum for the purposes of determining educational quality, the standards would have to meet with the Secretary's approval. Thus, the stage would be set for a constitutional challenge: Does the Constitution permit the Secretary of Education to require that students and faculty be selected on racial grounds as a condition of institutional participation in federal student aid programs? It should be noted that such participation is all but essential to the financial well-being and even the continued viability of a number of institutions. It should also be noted that the required racial preferment does not hinge upon any judicial or administrative finding of past or current discrimination by the institution; thus, the requirement is in no sense remedial of any racial wrong committed by the institution.

This constitutional issue cannot be disposed of merely by reference to the Supreme Court's decision in Regents of the University of California v. Bakke. ${ }^{83}$ Assuming one reads a majority of the Court as sharing the singular view of Justice Powell, that view would hold the achievement of racial diversity-and thus the grant of a racial preference-to be constitutionally permissible on educational grounds only in the context of a wider set of preferences adopted by the institution. Justice Powell's opinion in Bakke says, in effect, if an institution of higher education does not admit exclusively on the basis of standardized measures of aptitude and achievement, but takes account of a

81. H. CONF. REP. No. 630, 102d Cong., 2d Sess. 413, 526 (1992), reprinted in 1992 U.S.C.C.A.N. 528,640 (emphasis added).

82. According to Martin, supra note 61 , at $143 \mathrm{n} .116$, the Conference Report contained a typographical error.

83. 438 U.S. 265 (1978). 
variety of other factors such as musical ability, athletic prowess, and geographical distribution to achieve its idea of an educationally optimal student "diversity," then the Constitution does not limit the institution's ability to decide for itself to consider race as one among these factors. In fact, Justice Powell opined that the institution's liberty to fashion its curriculum and to select faculty and students "on educational grounds" imported a countervailing freedom from governmental constraint protected under the First Amendment. ${ }^{84}$ But Middle States's rules are to an opposite effect: Even though an institution exercised the same first amendment liberty to embrace an admissions policy of pure colorblindness, it would nevertheless have to go beyond the obligation of nondiscrimination under existing civil rights law to meet Middle States's rules of racial representation if it is to receive federal funds.

To avoid reaching the constitutional claim, the Secretary might assay an argument along this line: Just as Congress may delegate to an administrative agency a capacious power to make policy choices, ${ }^{85}$ so, too, may the Secretary recognize a similar range of discretion in the delegated accrediting associations. It follows, the argument would run, that so long as there is any colorable claim of a connection between the diversity rules and a determination of educational quality, the Secretary might remain agnostic about the weight of the claim and choose instead to defer to the judgment of the "generally recognized" and so arguably expert independent actor.

In that event, however, the Secretary could not shield his decision by pointing to the delegate's discretion for the simple reason that standards not disallowed by the Secretary are authorized. That is the plain meaning of the Act. And what the government authorizes it must defend, just as the delegate under Chevron must show its policy choice to be within the statutory ambit and to be constitutionally permissible. Put a little differently, one would think the federal government no less than "a state may not induce, encourage or promote private persons to accomplish what it is constitutionally forbidden to accomplish."

84. Id. at 312-13 (Powell, J.). The theory is discussed in Matthew W. Finkin, On "Institutional" Academic Freedom, 61 TEX. L. REV. 817 (1983), and more recently in J. Peter Byrne, Academic Freedom: A "Special Concern of the First Amendment," 99 YALE L.J. 251 (1989), and David M. Rabban, A Functional Analysis of "Individual" and "Institutional" Academic Freedom Under the First Amendment, 53 LAW \& ConTEMP. Probs. 227 (Summer 1990).

85. Chevron U.S.A., Inc. v. Natural Resources Defense Council, Inc., 467 U.S. 837 (1984), followed in Beth Rochel Seminary v. Bennett, 825 F.2d 478 (D.C. Cir. 1987).

86. City of Richmond v. J.A. Croson Co., 488 U.S. 469, 492-93 (1989) (citing Norwood v. Harrison, 413 U.S. 465 (1973)). The reach of this dictum could well be tested in another higher education setting. The rules of the Equal Employment Opportunity Commission ("EEOC") do not have the force of law; they are exhortations ex cathedra. The EEOC's rules on sexual harassment, Guidelines on Discrimination Because of Sex, 29 C.F.R. $\$ 1604.11$ (a) (1992), recommend the proscription of "verbal conduct of a sexual nature" that creates an "intimidating, hostile, or offensive working environment." A great many institutions of higher education, public and private, have taken the exhortation to heart, adopting rules modeled upon that of the EEOC to proscribe "verbal conduct of a sexual nature"-that is, sexual references in speech - which create an "offensive learning environment." There should be no doubt that government could not itself impose such a rule. See, e.g., Iota Xi Chapter of Sigma Chi 
A softer version of the argument would concede that the diversity policy would have to be defended, but it would take the same two closely interwoven factors-first, the connection between the racial complexion of the student body and educational quality, and second, the professional expertise of the private actor to draw that connection-as weighing in support of the constitutionality of the "diversity" rules as federally approved. Upon closer examination, however, neither factor can be made to bear quite all that much weight.

\section{A. The Relationship of "Diversity" to Educational Quality}

Arguing in defense of Middle States's rules, the Council on Postsecondary Accreditation pointed out that accrediting agencies had adopted "diversity" rules for different reasons:

Some accrediting bodies have adopted diversity standards because they are integral to the educational process in that their programs seek to prepare professionals to work effectively with diverse populations in diverse settings Others have adopted such standards and policies as part of their responsibility for promoting fair practice. A third group of agencies has acted to develop diversity criteria because they believe preparing students to live and work in a diverse society is an imperative educational objective.

One reason, COPA acknowledged, has less to do with an assessment of educational quality than with the agency's desire to promote its conception of the larger public good. This is the deeper root.

Recall that under the 1952 recognition-reliance system, racially segregated institutions were fully accredited; and when the evil of racial segregation was addressed, it was done by the United States Supreme Court and by later legislation and not by any act of the relevant regional accrediting association. In the early 1970s, when the Office of Education sought to have the accrediting agencies address discrimination in admissions and employment, it did so under the rubric of fostering "ethical practices" and not in the name of educational quality. To be sure, in the negotiations on point between the Commissioner and the accrediting community, the Office staff initially took the position that "unacceptable discrimination or arbitrary exclusion" adversely affected educational quality; ${ }^{88}$ but the elimination of discriminatory barriers is not identical to the erection of racial preferences. In seeking to enlarge minority admissions, the Office abandoned the claim of a connection to educational quality, in part because the staff had to concede that predominantly black (and

Fraternity v. George Mason Univ., 993 F.2d 386 (4th Cir. 1993) (holding that although university aimed to create an educational environment free of discrimination, it could not sanction a fraternity's "ugly woman contest" consistent with the First Amendment protection). Should it not follow that the EEOC may not "induce, encourage or promote" a private university to proscribe speech that the Constitution would forbid the government to proscribe?

87. Kenneth Perrin, Comments Concerning the Secretary of Education's Remand of the Petition of the Commission on Higher Education of the Middle State Association, submitted on behalf of the Council on Postsecondary Accreditation, at 5 (July 25, 1991).

88. ORLANS, supra note 7, at 77. See also Hearings, supra note 53, at 111 (testimony of John Proffitt). 
single sex) institutions did not adversely affect the quality of education. Consequently, when pressed by the accrediting agencies about what they should do if an expanded admission of minorities actually lowered educational quality, the staff expressed the hope that the agency would not act unless the diminution

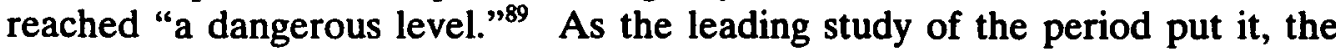
Office of Education's position was that "accrediting was not concerned solely with the quality of education but also with the public interest, and if it were necessary in serving the public interest for accrediting agencies to reduce the quality of education at least for a time and in some institutions, so be it." Though the accrediting agencies complied with the new criteria, they complained of being made enforcers of such "social policy" as affirmative action." When the Secretary abandoned the requirement in 1988, he did so because he concluded that the whole area was adequately dealt with under federal civil rights law.

In other words, prior to the Bakke decision in 1978, a requirement of "affirmative action," understood as an emphasis upon increasing the number of blacks admitted to institutions of higher education, was perceived by the Office of Education and the accrediting community as primarily a question of social policy distinct from and, at points, potentially inimical to educational quality as traditionally conceived. Tellingly, even in the Baruch case itself, Middle States criticized the college for emphasizing "traditional academic values" to the disregard of the values of "social justice and equity." O2 Only after Justice Powell fashioned his opinion on the permissible use of race did "diversity" become a generally accepted academic euphemism for racial preferences. ${ }^{93}$

89. ORLANS, supra note 7 , at 78 .

90. Id.

91. Hearings, supra note 53, at 222-33 (testimony of Frank Dickey).

92. See supra notes $63-65$ and accompanying text.

93. Cf. Paul D. Carrington, Diversity!, 1992 UTAH L. Rev. 1105, 1106 ("By borrowing Justice Powell's term for appropriate race consciousness, the current ['diversity'] movement is, not to mince words, a fraud."). So widespread has the euphemism become that in a recent issue of a trade paper one finds advertised the positions of "Diversity Coordinator," for the Thomas M. Cooley Law School, CHRON. Higher Educ., Nov. 3, 1993, at B49, and "Special Assistant to the President for Affirmative Action and Diversity," for the California State Polytechnic University, Pomona, id. at B39.

Ironically, maintaining student heterogeneity was a major argument earlier employed to defend a limit on the number of Jews to be admitted at Ivy League institutions. As Dean Hawkes at Columbia explained,

if a thousand men from France should present themselves to Columbia College for admission and were better qualified to pass our entrance examinations than young men from our local clientele, I would feel that some step ought to be taken so that it would be impossible to admit them all .... The same kind of remark may be made in regard to Jews, colored people, and other groups that are more or less distinctive. We ought to be glad to have as many of each kind as in our judgment the institution can stand but to say that there should be no limit to the number of men of a given type who may present themselves to College, seems to me a surrender on the part of the administration of one of the most important responsibilities that they bear.

Quoted in Harold Wechsler, The Qualified StUdent: A History of Selective AdMission in AMERICA 167-68 (1977); see also MARCIA GRAHAM SYNNOTT, THE HALF-OPENED DOOR: DisCRIMINATION IN ADMISSIONS AT HARVARd, YALE AND PRINCETON, 1900-1970 (1979). 
Accordingly, analysis of the "diversity" requirement better proceeds from the section of the 1992 Higher Education Act that insulates the agencies from federal scrutiny when the standards at issue are not "provided for" in the Act and do not "relate to" the determination of educational quality for the purposes of the Act.

Nevertheless, as COPA argued, some accrediting agencies have couched their diversity requirements in terms of Justice Powell's reasoning. They have drawn a connection between the racial complexion of the student body and the quality of education, either closely, adverting to the actual classroom experience, or more broadly, adverting to the role of race in the campus culture. ${ }^{94}$ Each of these contentions should be taken in turn.

The first argues the importance of the racial mix to the vitality of the classroom. And intuitively, having a number of black students, especially from inner city backgrounds, in some aspects of the social sciences or humanities, such as certain offerings in sociology, literature, or history, may well result in a livelier classroom discussion than having the class composed exclusively of white farm boys. ${ }^{95}$ But the same could not be said of a class in differential calculus, organic chemistry, Romanesque architecture, or international trade-nor of a survey of Kant, a seminar in the Noh, or a section of Swahili; that is, of offerings in all the hard sciences, ${ }^{96}$ in most of the arts and letters, and even much of the social sciences. In other words, it is questionable whether the connection is sufficiently powerful to warrant government to go beyond a policy of nondiscrimination to impose more in the way of a racial preference than the institution believes its educational environment to require.

Even were there to be a more powerful connection between "diverse" students and the robustness of intellectual exchange, that closer connection would not necessarily preordain how the constitutional question should be resolved. To illustrate, no single nonacademic attribute would seem to contribute more to intellectual diversity in the classroom than religion. Many

94. The amicus curiae brief of the American Association of University Professors in Bakke argued that a faculty could draw these connections in fashioning its institution's admissions policy. Brief of the American Association of University Professors, Amicus Curiae, Regents of the Univ. of Cal. v. Bakke, 438 U.S. 265 (1978) (No. 76-811). It ought to be noted, however, that rather little social science was available to support the connection in either the classroom or campus context. The argument was, rather, that a faculty could exercise its judgment to draw a connection-or not. The author was the principal drafter of the Association's brief.

95. Cf. Regents of the Univ. of Cal. v. Bakke, 438 U.S. 265, 316 (1978) ("A farm boy from Idaho can bring something to Harvard College that a Bostonian cannot offer." (quoting the Harvard College program)).

96. This is not to deny that the application of science is influenced-some might say "biased"-by the larger, some might say "dominant," culture, nor to deny that such influence could be found in the choice of areas worthy of scientific inquiry. See generally MARK S. FRANKEL, VIEWING SCIENCE AND Technology through a Multicultural Prism: Project RePORT: AtTracting Minority SCHOLARS INTO RESEARCH ON VALUES AND ETHICAL ISSUES IN SCIENCE AND TECHNOLOGY (1993). But it is to maintain that the content and accessibility of a body of scientific knowledge has nothing to do with the student or researcher's race or ethnicity: There is no more an African-American Astronomy than there was a Jewish Physics. On the latter, see A. BEYERCHEN, SCIENTISTS UNDER Hitler: Politics and the Physics Community in THE THIRD Reich (1977). 
religions contain historically rich, complex, and subtle systems of thought that speak to life in all its parts: to ethics; to family; to banking and currency, commerce and agronomics; to work; to war; to iconography and the representation of reality; to symbolism, meaning, and the manner of expliciting a text; to law. Yet there seems little doubt that government could not command that more (or fewer) devout Muslims, Catholics, or Jews be admitted as a condition of federal support, even though that command would seem to be far more powerfully related than race to the enrichment of the classroom experience for all.

Consequently, as COPA argued, the "diversity" requirement may be predicated less upon the classroom experience than upon the relevance of the racial mix to the "student culture," so to the institution's larger educational ends. As Robert H. Atwell, President of the American Council on Education, argued in defense of Middle States,

diversity among institutions does not satisfy the need for diversity within institutions. As our nation has progressed beyond the era of legal segregation, and as the composition of our population has changed dramatically, many people in higher education and in other sectors have come to understand the critical importance of recognizing and cultivating the diversity that exists among the various cultures that compose the United States. Applying this concept to higher education requires a comprehensive approach that encompasses the makeup of the faculty, student body, and staff; the curriculum offered by the institution; and the climate on the campus itself. ${ }^{97}$

Some institutions do see a close connection between the mix of students they select and their larger mission in the world, a mission that may transcend the "traditional academic values" imparted and explored in the classroom, studio, and laboratory. To some, Berea College supplies a pointed example; ${ }^{98}$ their very reason for being may require them to adopt race conscious policies, which institutional choice Justice Powell would take to be protected under the First Amendment. But others might choose to chart a different educational course, which choice one would imagine to be equally protected by the First Amendment. It would be possible for an institution to take the position that the educational experience it seeks is an intense engagement with the eternal verities of the Western Tradition that, it maintains, speak universally irrespective of personal histories or group affinities. This institution might seek an

97. Robert H. Atwell, The Dangers of U.S. Intervention in Accreditation, CHRON. HIGHER EDUC., Nov. 20, 1991, at A52 (emphasis in original). And "applying this concept" to its logical conclusion would result in a finely tuned system of racial and ethnic quotas to assure the necessary representation- of just the right number, no more or less-of all the "various cultures" in order to "cultivate" that very diversity. Justice Powell recognized this possibility as inherent in the logic of racial preference, but he deemed it "inconceivable" that an institution would press the logic that far, to what he termed an "illogical end." Bakke, 438 U.S. at 315. But the end is not illogical at all, given the presumption, and Justice Powell did not explain why he thought it was.

98. See Berea College v. Kentucky, 211 U.S. 45 (1908), discussed in Finkin, supra note 84 at 835-36. Berea College, having been convicted of violating a Kentucky law which forbade the instruction of blacks and whites in the same institution, challenged the state action on Fourteenth Amendment grounds. Finkin, supra note 84, at 835-36. The Court, finding no impairment of the institution's freedom to teach, affirmed the conviction. Id. 
intellectually curious and highly motivated group of students exclusively by color-blind processes. Any injection of race as a consideration of admission at this institution would be profoundly offensive to the values it embraces, to its educational mission in the larger world.

In such a case, one would expect the accrediting agency to defer to the institution's purposes and policies, just as it would be expected to with regard to women's colleges, black colleges, or colleges founded by and catering to religious and ethnic groups. But Middle States's rules neither pay respect to the principle of institutional autonomy nor give deference to institutional pluralism in the matter of racial preferences. Just as the President of the American Council on Education said: Diversity "among" is no substitute for diversity "within." And when he wrote along that line to the Secretary of Education in support of the Middle States Association, he employed the imperative:

To develop the potential of all individuals and groups within our society, colleges and universities must ensure that diversity is reflected in every aspect of institutional life-students, faculty, staff, curriculum, governance. Every person affected by the institutions of a democratic society-and those include its colleges and universities-deserves the opportunity to share in imagining, building, and running them. Creating such opportunity for individuals and groups that previously have been excluded or underrepresented provides them with a critical entree to participation in our democracy, and is essential to its preservation.9

What was defended as a precondition of a qualitatively superior campus culture thus collapses back into a social manifesto about the role of higher educational institutions as gatekeepers to the wider world. The inconvenient fact for that proposition is that society is very deeply divided about the preferential use of race for that purpose, ${ }^{100}$ as is the academy. ${ }^{101}$ Accordingly, the question turns to what special competence or professional expertise Middle States would have to impose its vision of the social role of higher education upon dissenting academies.

99. Letter from Robert H. Atwell, President of the American Council on Education, to Lamar Alexander, U.S. Secretary of Education (August 30,1991) (on file with author) (emphasis added). President Atwell buttressed this position by reference to Justice Powell's opinion in Bakke and Powell's reliance in that opinion upon Keyishian v. Board of Regents, 385 U.S. 589 (1967), in which the Court noted the importance to the nation of leaders educated through wide exposure to ideas. Keyishian, a loyalty oath case, involved institutional freedom from state controls.

100. See, e.g., JAMES R. KLUEGEl \& ElIOT R. SMITH, BELIEFS ABout INEOUALITY: AMERICANS' VIEWS OF WHAT IS AND WHAT OUGHT TO BE 202 (1986) (about $10 \%$ of whites favor preferential treatment of blacks in college admissions, though a majority of whites support training programs to help blacks compete for jobs; a majority of blacks favor preferential treatment, but $70 \%$ of blacks favor access based only on evidenced ability).

101. See, e.g., AleXANDER Astin ET AL., The UCLA CAMPUS Climate for DIVERSITY: Findings FROM A CAMPUSWIDE SURVEY CONDUCTED FOR THE CHANCELLOR'S COUNCIL ON DIVERSTTY (1991) (reporting that although $92 \%$ of the faculty responding agreed that "diversity" (otherwise undefined) is good for UCLA, $67 \%$ agreed that too many unprepared students were being admitted in pursuance of "the goal of diversity," and $45 \%$ agreed that "affirmative action leads to the hiring of less qualified faculty and staff"); see also Carl A. Auerbach, The Silent Opposition of Professors and Graduate Students to Preferential Affirmative Action Programs: 1969 and 1975, 72 MiNN. L. REV. 1233 (1988). 


\section{B. The Institutional Competence of Accrediting Agencies}

The argument for institutional competence requires that attention be directed to just who these accreditors are to whom such deference is due. In defense of the Middle States Association, Robert H. Atwell stressed that "the institutions themselves" set the standards:

Accreditation is not only voluntary, it is participatory. Institutions themselves control the operations of the accrediting bodies. They, not the accrediting agencies' small professional staffs, set the policies and standards. Accreditation is carried out not by a faceless bureaucracy, but by faculty members and administrators who make up the various visiting teams and commissions. Those reviewers must ascertain whether an institution is meeting the accrediting body's criteria as well as the educational goals that it has set for itself. ${ }^{102}$

In essence, what calls for deference is the fact of a collectively agreed upon standard.

One has to be very careful about the claim. The "institutions themselves" is an abstraction. The votes in Middle States, or any other regional association, are not cast after debate and action by the deliberative bodies of each of the member institutions-bodies that might have to act upon the institution's own policies. "The institution" is represented by its president or his delegate, and, in that sense, the regionals are composed not of the "institutions themselves" but of their administrations. ${ }^{103}$ As in any association, some members are more active in its affairs than others. Not to put too fine a point on it, the regional associations tend to be dominated by presidents and deans from non-flagship public institutions and relatively unselective private colleges. ${ }^{104}$

It is hardly shocking to suggest that there is a political dimension to the decisionmaking in these associations; yet that fact should serve as sobering caution to the too-ready assumption of disinterested expertise. ${ }^{105}$ To take an

102. Atwell, supra note 97. The first sentence is not quite accurate: Accredition is "voluntary" only for institutions that do not wish to receive federal funds or to receive students with federally insured loans. The last sentence is also misleading, for as the Westminster Theological Seminary dispute evidences, Middle States's rules substitute its ends for the mission the institution set for itself-in that case, to the disregard of the institution's religious commitment.

103. "[T]he regional and proprietary school agencies represent the managers and administrators of institutions, not their students," nor their faculties. ORLANS, supra note 7, at 95.

104. The Carnegie Foundation for the Advancement of Teaching opined that "higher education does not take accreditation seriously enough" and noted that "[f]aculties and administrators from our most esteemed colleges and universities have not been active participants in the process." CARNEGIE FOUNDATION FOR THE ADVANCEMENT OF TEACHING, CONTROL OF THE CAMPUS 26 (1982) (quoting Arthur E. Levine, Reflections on Accreditation (March 1982) (unpublished manuscript, on file with author)). And the "blue ribbon" National Commission on Higher Education Issues recommended that accrediting agencies, "especially the policy-making bodies and evaluation teams, should include more administrators and faculty members from institutions known and respected for their high quality." NATIONAL COMM'N ON HIGHER EDUC. ISSUES, TO STRENGTHEN QUALITY IN HIGHER EDUCATION, reprinted in Hearings, supra note 11, at 53,63. The latter was not taken kindly by the accrediting community.

105. See Ronald W. Tobin, The Age of Accreditation: A Regional Perspective, 80 ACADEME 26 (1994) (reporting on the process whereby the Western Association of Schools and Colleges (the "WASC") adopted its diversity rules). Professor Tobin, Vice Chancellor for Academic Programs at the University 
area unconnected to the diversity controversy, all the regional associations require an institutional commitment to academic freedom as a criterion of accreditation. They could scarcely do less, inasmuch as academic freedom is virtually a defining condition of higher education. ${ }^{106}$ But none police that requirement or express any concern to an errant administration, save when called upon by the most public of controversies. One might defend the reluctance to act on the need to husband scarce resources and the arguably greater competence of other fact-finding bodies potentially active in these cases, such as the courts or the American Association of University Professors. That prudential ground, however, does not explain why these agencies do not act after the facts have been found, after institutions have been investigated and their conditions found wanting. In fact, the accrediting agencies do not even act when faculty members have been disciplined for complaining to them; that is, when the integrity of their own processes are implicated. One need not go so far as to accuse the regional associations of "cronyism"107 to explain why a group of college administrators, largely from institutions whose traditions or circumstances might at any moment thrust them in an unflattering light as actors in an academic freedom dispute and who share the bonds of mutual respect and collegiality that come from engagement in a common enterprise, might be reluctant to call one another to public account in such situations.

However, these agencies have addressed academic freedom issues when they have felt the public necessity, that is, in extraordinarily visible cases. An inspection team of the Middle States Association recently did address the issue in one such case: when Professor Charles Curran was removed from his position on the faculty at Catholic University because the Holy See held his writings of several years previous-writings which Curran refused to recant-to be such as to deprive him of his "canonical mission" to teach Catholic Theology. The Middle States team concluded that the University's trustees had the latitude to decide that allowing Professor Curran to continue would countenance teaching opposed to the official position of the Church. ${ }^{108}$ Middle States accordingly

of California at Santa Barbara and the University's delegate to the Western Association, reported the reluctance of some small college administrators to support a motion for a more extended review of the question "out of a desire not to offend the WASC staff which is responsible [for] campus evaluations." Id. at 32 .

106. See generally Symposium, Freedom and Tenure in the Academy: the Fiftieth Anniversary of the 1940 Statement of Principles, 53 LAW \& CONTEMP. ProBS. (Summer 1990), and the bibliography compiled at 381-92.

107. Though some have made that charge; the references are supplied in Finkin, supra note 21, at 394 n.58.

108. Report to the Faculty, Administration, Trustees, Students of the Catholic University of America by an Evaluation Team Representing the Commission on Higher Education of the Middle States Association of Colleges and Schools (1990) (on file with author). The team observed:

It was the Board of Trustees' decision to withdraw Father Curran's authority to teach Catholic theology, although the immediate stimulus came from the Holy See's letter.

It is clearly the view of the Board of Trustees that it would be contrary to the raison d'être of The Catholic University of America to countenance advocacy of what it regards as falsehood in an area where it has an obligation to promote truth. It also could not 
conceded that the trustees' interpretation of the institution's relationship to the Church could trump both Middle. States's. standards and the institution's previously stated commitment to academic freedom. ${ }^{109}$

It is arguable that Middle States took a principled position in the Catholic University matter, in deference to religious freedom. ${ }^{110}$ But Westminster Theological Seminary's interpretation of its relationship to the sponsoring church stood on no such privileged ground when confronting Middle States's diversity rule requiring that women be placed on its governing board. Middle States's action in that case is hard to square with its contemporaneous inaction in the Catholic University case, unless requiring a church-related university to permit a dissenting academic of unquestioned competence to continue to teach is less vitally connected to fostering an academic atmosphere of intellectual diversity than is requiring a woman to be appointed a trustee.

Again, it should be no more surprising to find a political dimension in the workings of agencies of accreditation than in the Church or any other eleemosynary institution. But the Middle States's actions with respect to the Westminster Theological Seminary and Baruch College lend weight to Paul Carrington's observation that the politics of accrediting agencies renders them especially vulnerable in the matter of "diversity" to current ideological fashion ${ }^{111}$ - to

countenance the claim that the position opposed to the official magisterium is a position of the Catholic Church.

Id. at 35 . It concluded:

No one questions the good faith of the Administration or Board in dealing with the matter.

All members of the team agree that there is a clear need to state the University's understand-

ing of the meaning of academic freedom and to promulgate it to internal and external communities. The issue must be settled to permit the University community to focus its activities on its future.

And it noted that such an effort was being undertaken. Id. at 36 .

109. The committee of investigation of the American Association of University Professors observed that Professor Curran's professional publications had long been known to the University, whose rules would seem to have spoken unequivocally to his situation:

"As a University," the faculty handbook states under "Aims of the University," the Catholic

University

is essentially a free and autonomous center of study and an agency serving the needs of human society. It welcomes the collaboration of all scholars of good will who, through the process of study and reflection, contribute to these aims in an atmosphere of academic competence where freedom is fostered and where the only constraint upon truth is truth itself (Part $I$, p. 32).

And in $1971, \ldots$ the university reported to the Middle States Association of Colleges and Schools that a "university conceived as a community of scholars must be free of arbitrary and extrinsic constraints, be they civil or ecclesiastical. Institutional autonomy and academic freedom are essential conditions of university life and growth." In the light of the present case, the investigating committee must wonder if the university could in good conscience make the same statement to the Middle States Association today.

Academic Freedom and Tenure: The Catholic University of America, ACADEME, Sept.-Oct. 1989, at 27, 38.

110. Compare Michael W. McConnell, Academic Freedom in Religious Colleges and Universities, in FREEDOM AND TENURE IN THE ACADEMY 303 (William W. Van Alstyne ed., 1993) with Judith W. Thomson \& Matthew W. Finkin, Academic Freedom and Church-Related Higher Education: A Reply to Professor McConnell, in id. at 419.

111. Carrington, supra note 93, at 1108. 
capture by political correctness. ${ }^{112}$ In fine, the more accrediting agencies seek to apply a larger social agenda, the less they should be deferred to on any ground of professional expertise.

\section{The Escape Clause}

Briefly to rehearse, the Act denies the Secretary the power to establish standards "not required" by the Act, and assures accrediting agencies the power to adopt standards "not provided for" by the Act. Historically and substantively, the diversity rules would better be submitted by the accrediting agencies as exercises in social policy not directly connected to the narrow function of determining educational quality for the purposes of federal support. Were this to be the case, the Secretary would have no power over the "diversity" rules and could not be called upon legally to defend them. The Secretary might nevertheless continue the eligibility of a nonaccredited institution if the reason for its nonaccreditation is "related to" the institution's religious mission and is "not related to" the accreditation standards "provided for" in the Act. Presumably, Westminster Theological Seminary's eligibility could be continued under the current law. But because Baruch College is not a religiously affiliated institution, it could find no shelter for its failure to abide by Middle States's "diversity" rules. ${ }^{113}$ Indeed, according to Jeffrey Martin's account of the legislative process, in which he was involved as General Counsel to the Department of Education, the conferees chose this language to insulate religious institutions from "diversity" rules, while allowing those rules to apply to nonreligious institutions. ${ }^{114}$ Thus, the current Act tacitly would allow the Middle States Association to accomplish what Congress declined directly to require. The question then becomes whether it is permissible for Congress to condition an institution's eligibility upon passing muster with social policies set by a private agency over which the government has denied itself any administrative control.

On this issue, institutional competence is of paramount import; but, it plays out in a very different direction, on genuine nondelegation grounds. Assuming arguendo that Congress could attach some scheme of racial preference to the receipt of federal education funds, ${ }^{115}$ it does not follow that Congress, in exercise of its power under the Fourteenth Amendment, could delegate that decision ${ }^{116}$ even to the Secretary of Education-let alone to private parties.

112. Id. at 1193 .

113. This reading of the Act is shared by Martin, supra note 61 , at $143 \& \mathrm{n} .116$.

114. Id. at $143 \& \mathrm{nn} .115-16$.

115. A proposition by no means obvious. See William W. Van Alstyne, Rites of Passage: Race, the Supreme Court, and the Constitution, 46 U. CHI. L. REV. 775 (1979).

116. Compare Fullilove v. Klutznick, 448 U.S. 448 (1980) (upholding the constitutionality of the Public Works Employment Act of 1977 , which required that at least $10 \%$ of federal funds granted to public works projects be granted to minority contractors) with City of Richmond v. J.A. Croson Co., 488 U.S. 469 (1989) (holding a city's plan requiring prime contractors awarded city construction contracts to subcontract at least $30 \%$ to minority subcontractors to fail strict standard scrutiny). 
Congress is constitutionally charged with the nondelegable responsibility to decide the most fundamental questions of public policy-to decide "between conflicting proposals presented by clashing interests."117 As James Freedman put it,

[w] hen a constitutionally-assigned power is by its nature peculiarly resistant to the formulation of governing principles and standards, the indications become strong that the Framers placed a deep reliance for its proper exercise upon the unique qualities-the institutional competence-of the body to which it was assigned. ${ }^{118}$

The more fundamental those policy choices are, the more deeply those interests clash, the greater is the obligation of Congress alone to decide. It is difficult to conceive of any policy choice more fundamental, of any more deeply felt clash of interests, of any question more resistant to the "formulation of governing principles and standards" than a federal mandate that some be advantaged over others on account of race.

\section{$\mathrm{V}$ \\ CONCLUSION}

In 1952, Congress fashioned a facility based on the responsible belief that well-recognized accrediting agencies existed that were making professional judgments of educational quality irrespective of the government's need to rely upon them. In 1992, Congress realized that a great many of these agencies had been called into being in order to fulfill the mission government expected of them. They could no longer be considered mere facilities. They became by statute what they had gone far to become by administrative act and their own acquiescence, delegates of the state.

Much of that delegation is nevertheless saved from successful constitutional attack: The agencies' qualitative standards are subject to administrative control; they operate subject to administrative oversight, both at large and in discrete cases; and due process must be observed.

Much is saved, but, perhaps, not all. The government has denied itself any administrative power over an agency's application of a standard not "related to" the accreditation standards "provided for" in the Act; and a nonreligious institution refused accreditation for its failure to abide by such a standard would be denied eligibility to participate in federally funded student loan programs unless the institution could somehow create or turn to another institutional accrediting agency that the Secretary of Education would recognize. In other words, the Act frees the accrediting agencies to adopt ideological or other

117. Freedman, supra note 24, at 315 (quoting SOTIRIOS BARBER, THE CONSTITUTION AND THE DELEgation OF CONGRESSIONAL POWER 38 (1975)).

118. Id. Even by a different legal route, requiring a "clear statement" to limit "the reach of delegation when agency action infringes upon constitutional norms," Harold J. Krent, Delegation and Its Discontents, 94 Colum. L. REv. 710,713 (1994), the lack of any congressional authorization for the adoption of diversity rules should render the Secretary's authorization of them ultra vires his authority under the Act. See discussion of an analogous issue, id. at 743-44. 
requirements unrelated to determinations of educational quality, and requires nonreligious institutions to comply with them as a condition of federal program participation. $^{119}$

One approach to the constitutionality of this requirement would assimilate all the actions of the accrediting agency as government action whether or not "related to" the purposes of the Act. By this approach, the lack of administrative oversight of "unrelated" policies would not preclude judicial accountability. Consequently, the accrediting agency would be required to defend all its policies on constitutional grounds just as if these policies were required by the state itself. ${ }^{120}$ By this reasoning, an accrediting agency could not adopt an irrational policy, for example, requiring that a preference be given in staff selection to those born under a specified zodiacal sign. But just as Congress could require a preference in employment to be given to qualified veterans, there would seem to be no constitutional infirmity going to the substance of the policy were the legislature's delegate to require an analogous veterans preference in faculty and staff selection. ${ }^{121}$

In other words, the "state action" approach would allow the accrediting agency to apply a policy unrelated to determining educational quality so long as that policy would separately withstand constitutional scrutiny were it to have been adopted by the state directly. That is as far as the doctrine would reach. The question presented, however, is of the constitutionality of the condition allowing the agencies to apply those policies, not the constitutionality of the policies themselves. On that account, the Supreme Court has explained that "our 'unconstitutional conditions' cases involve situations in which the government has placed a condition on the recipient of the subsidy rather [than] on a particular program or service, thus effectively prohibiting the recipient

119. There may be a less intrusive ground for the accrediting agencies to take on the question of racial preferences. The Commission on Institutions of Higher Education of the North Central Association adopted a Statement on Access, Equity, and Diversity that "urges each institution to examine its own character, to find its proper balance between the benefits of diversity and the values of community, and to communicate these views to the public." NORTH CENTRAL ASs'N OF COLLEGES AND SCH., A HANDBOOK OF ACCREDITATION 77, 78, app. D (1992). Though the Statement is normatively laden elsewhere, the actual accreditation requirement calls only for self-assessment and a public statement upon the question. There are circumstances when government's forcing a person to speak to a question upon which the person would wish to remain silent could violate the First Amendment, but it is arguable that a rule requiring institutions of higher education to make their admissions policies public, whatever they may be, is not such a case.

120. This approach is analyzed in Martin, supra note 61 , at $144-46$.

121. Where a state constitution insulates the state university from the reach of a state veterans' preference law, e.g., Winberg v. University of Minn., 499 N.W.2d 799 (Minn. 1993), the university's participation in the federal program to which that condition might be attached would, so to speak, trump the prohibition. In any event, that constitutional prohibition would limit only the state's own legislative power. Id. It is conceivable, however, that the state's constitutional equal protection guaranty would limit the state university's ability to adopt racial preferences. In that case, it is arguable that the university would be constitutionally prohibited from participating in the federally funded program were that preferential condition to be attached. See William W. Van Alstyne, "Thirty Pieces of Silver" for the Rights of Your People: Irresistible Offers Reconsidered as a Matter of State Constitutional Law, 16 HARv. J.L. \& PUB. POL'y 303 (1993). 
from engaging in the protected conduct outside the scope of the federally funded program."122 But this legislation does precisely that: It allows accrediting agencies to apply social policies unrelated to their determination of educational quality to impinge upon the liberties of institutions of higher education for purposes "outside the scope of the federally funded program." This condition is, by definition, arbitrary, and no assimilation of the accrediting agency as an agent of the state can save it.

122. Rust v. Sullivan, 500 U.S. 173, 197 (1991) (emphasis both omitted and added). 